\title{
Performance and health responses of dairy calves offered different milk replacer allowances
}

\author{
A. Bach, ${ }^{*} \dagger^{1} M$. Terré, $\dagger$ and A. Pinto $\dagger$ \\ *Institució Catalana de Recerca i Estudis Avançats (ICREA), 08010 Barcelona, Spain \\ †Department of Ruminant Production, Institut de Recerca i Tecnologia Agroalimentàries (IRTA), Torre Marimon, 08140 Caldes de Montbui, Spain
}

\begin{abstract}
Eighty female Holstein calves $(12 \pm 4.1 \mathrm{~d}$ of age and $42 \pm 4.3 \mathrm{~kg}$ of $\mathrm{BW}$ ) were collected from different herds, brought to the study site, and blocked by age and assigned to either a $6 \mathrm{~L} / \mathrm{d}$ maximum daily milk replacer (MR) allowance (LMR) or a maximum MR allowance of $8 \mathrm{~L} / \mathrm{d}$ (HMR). Calves were kept in individual hutches until $52 \mathrm{~d}$ of age and then moved into pens, forming groups of 10. All calves had ad libitum access to a mash starter feed. Calves in both treatments received the MR distributed in 3 separate allotments between 1 wk after the beginning of the study and 52 $\mathrm{d}$ of age. Then, all calves were moved to group pens and preweaned by offering $2 \mathrm{~L} /$ calf of the same MR twice daily in a trough until the age of $59 \mathrm{~d}$, when MR offer was further reduced to a single dose of $2 \mathrm{~L}$ until the age of $73 \mathrm{~d}$, when all calves were completely weaned. Individual starter feed and MR consumption was recorded on a daily basis until $52 \mathrm{~d}$ of age, and on a group basis until weaning time. Body weight was measured at the beginning of the study and at 52 (preweaning), 73 (weaning), and 110, 160, and $228 \mathrm{~d}$ of age. Solid feed consumption (mean $\pm \mathrm{SE}$ ) was greater in LMR $(821 \pm 42.1 \mathrm{~g} / \mathrm{d})$ than in HMR calves $(462 \pm$ $42.1 \mathrm{~g} / \mathrm{d}$ ) between $42 \mathrm{~d}$ of age and $52 \mathrm{~d}$ (preweaning). As expected, as age increased, solid feed consumption increased, and LMR showed a more marked increase than HMR calves. Despite the greater solid feed intake of LMR calves, HMR grew faster than LMR calves until preweaning time, but from preweaning to weaning, LMR calves grew more than HMR calves (977 vs. 857 $\pm 30.7 \mathrm{~g} / \mathrm{d}$, respectively; mean $\pm \mathrm{SE}$ ). No differences in feed efficiency were observed. While calves were individually housed, no differences were observed in the incidence of bovine respiratory disease or diarrhea between treatment groups. We concluded that, under the milk regimen, age range of calves, and weaning method used in the current study, before preweaning,
\end{abstract}

Received April 9, 2013.

Accepted August 27, 2013.

${ }^{1}$ Corresponding author: alex.bach@irta.cat
HMR calves grow more than LMR calves, but between preweaning and weaning, LMR grow more than HMR calves, overcoming the difference in BW at preweaning. As a result, with the weaning scheme followed herein, providing more milk does not ensure greater performance; no differences are obtained in BW at weaning and at $228 \mathrm{~d}$ of life. Also, based on solid feed consumption patterns seen in this study, we determined that the optimum age to reduce MR allowances and foster solid feed intake is around $45 \mathrm{~d}$ of age.

Key words: efficiency, intake, starter

\section{INTRODUCTION}

For several decades, milk offered to calves has been restricted to keep feed and labor costs low (Kehoe et al., 2007) and foster solid feed intake and rumen development (Davis and Drackley, 1998). More recently, it has been shown that fostering rapid growth early in life may have positive consequences on future milk performance (Bach and Ahedo, 2008; Bach, 2012; Soberon et al., 2012) and survivability to second lactation (Bach, 2011). If rapid growth $(>700 \mathrm{~g} / \mathrm{d})$ is sought, feeding increased amounts of milk is necessary. However, calves fed high milk allowances tend to struggle during transition onto solid feed, and part of the growth advantage achieved before weaning is lost due to (1) diminished consumption of nutrients (Davis and Drackley, 1998) and (2) reduced digestibility (Terré et al., 2007; Hill et al., 2010), most likely due to insufficient development of the reticulorumen (Baldwin et al., 2004) and inadequate establishment of the rumen microflora (Terré et al., 2007) as a consequence, in part, of the weaning method used (too abrupt in many instances). Gradually weaning calves over an extended period of time has been proposed as a solution to minimize these negative consequences (Khan et al., 2007; Roth et al., 2009). Another alternative has consisted of offering poor-quality chopped hay (Castells et al., 2012) before weaning to foster solid feed intake (Castells et al., 2013; Montoro et al., 2013).

On the other hand, the effect of providing increased amounts of milk or milk replacer (MR) on health 
seems to be inconsistent. A priori, one would expect that offering more MR would improve animal health due to improved supply of nutrients, but some studies report increased diarrhea (Huber et al., 1984; Quigley et al., 2006) and impaired response to vaccination (Pollock et al., 1994), some report no changes (Nonnecke et al., 2003; Borderas et al., 2009), and some others report improvements in health (Nocek and Braund, 1986). Furthermore, to our knowledge, previous studies have focused on diarrhea and the potential effect of high MR allowances on bovine respiratory disease (BRD) has only been assessed by Borderas et al. (2009). Furthermore, most of the studies that evaluate the effect of milk allowance in young calves end at weaning or about 2 wk after weaning (Díaz et al., 2001; Cowles et al., 2006; Hill et al., 2009). The objectives of this study were to evaluate the short- and medium-term effects on growth performance and health of calves receiving 2 different milk allowances.

\section{MATERIALS AND METHODS}

\section{Animals and Experimental Design}

Eighty female Holstein calves $(12 \pm 4.1 \mathrm{~d}$ of age and $42 \pm 4.3 \mathrm{~kg}$ of BW) were collected from 43 dairy herds and brought to the study site (Rancho Las Nieves, Mallén, Spain) on June 6, 2012. Upon arrival, calves were blocked by age (one block of 40 calves with an age of $9 \pm 2.6 \mathrm{~d}$ and initial BW of $41 \pm 3.5 \mathrm{~kg}$, and a second block of 40 more calves with an age of $16 \pm 1.4 \mathrm{~d}$ and initial BW of $43 \pm 4.6 \mathrm{~kg}$ ) and then randomly assigned (which should remove any potential carryover effects of previous life experience before entering the study) to either a maximum daily MR allowance of $6 \mathrm{~L} / \mathrm{d}(\mathbf{L M R})$ or $8 \mathrm{~L} / \mathrm{d}$ (HMR). All calves in both treatments were managed similarly under the approval and supervision of the Animal Care Committee of the Institut de Recerca i Tecnologia Agroalimentàries (IRTA, Barcelona, Spain). Calves were kept in individual hutches $(1 \times 1.6$ $\mathrm{m})$ until $52 \mathrm{~d}$ of age. Therefore, calves that entered the study at $9 \mathrm{~d}$ of age spent 1 more week ( $42 \mathrm{~d}$ in total) in individual hutches than calves that entered at 16 d of age (spent a total of $35 \mathrm{~d}$ ). Calves were moved into pens $(6 \times 3 \mathrm{~m})$ in groups of 10 animals, with an average age of $52 \mathrm{~d}$. Calves were bedded with chopped straw every other day. From enrollment in the study, all calves had ad libitum access to a mash starter feed (Table 1) and water, and were bottled-fed $2 \mathrm{~L}$ of MR ( $25 \% \mathrm{CP}, 19 \%$ fat, and $5.18 \mathrm{Mcal}$ of gross energy $/ \mathrm{kg}$ ) at a $10 \%$ dilution rate 3 times per day (at 0700, 1500, and $2200 \mathrm{~h}$ ) during the first week of the study to ease the adaptation of the calves to new environment and MR (as commonly done in contract heifer operations).
Then, calves in the LMR group continued to receive 6 $\mathrm{L}$ of $\mathrm{MR} / \mathrm{d}$ in 3 separate doses (at the same times as in the first week) but at a $12.5 \%$ dilution rate, whereas calves in the HMR received $8 \mathrm{~L}$ of $\mathrm{MR} / \mathrm{d}$ at $12.5 \%$ distributed in 3,3 , and $2 \mathrm{~L}$ at 0700,1500 , and $2200 \mathrm{~h}$, respectively. At the age of $52 \mathrm{~d}$, all calves were moved to pens and were preweaned by offering $2 \mathrm{~L} /$ calf of the same MR (at $12.5 \%$ dilution) at 0700 and $1500 \mathrm{~h}$ in a trough until the age of $59 \mathrm{~d}(4 \mathrm{~L} / \mathrm{d})$. Then, at $59 \mathrm{~d}$ of age, MR offer was further reduced to a single daily dose of $2 \mathrm{~L}$ at $12.5 \%$ dilution rate at $0700 \mathrm{~h}$ until the age of $73 \mathrm{~d}$, when all calves were completely weaned. When moving calves out of the individual hutches, groups were formed exclusively with animals pertaining to the same treatment (i.e., all LMR calves were distributed in 4 different pens, and all HMR calves were distributed in 4 additional pens).

When calves were moved to groups, they continued to receive the same starter feed as that received when individually housed and $1 \mathrm{wk}$ later were moved to a dry TMR (Table 1) until $110 \mathrm{~d}$ of life. Then, they received a different dry TMR until the age of $160 \mathrm{~d}$ (Table 1), and then another TMR (Table 1) until the age of 228 d. After weaning, all animals were handled and fed in exactly the same manner.

All calves were weighed using an electronic scale upon arrival, and at 52 (preweaning), 73 (weaning), and 110, 160 , and $228 \mathrm{~d}$ of age. Individual starter feed and MR consumption was recorded on a daily basis until $52 \mathrm{~d}$ of age, and on a group basis until weaning time (73 d of age). Throughout the study, on a daily basis, each calf was checked for incidence of diarrhea or BRD. A calf was considered to have diarrhea when assigned a fecal score $\geq 3$ using a 4 -point scale following Larson et al. (1977): 1 = firm, $2=$ soft, $3=$ runny, and $4=$ liquid. Similarly, an animal was considered to have BRD when she presented 1 or several of the following signs: labored breathing, coughing, droopy ears, eye discharge, or nasal discharge along with a fever.

Last, starter feed and TMR were analyzed for DM $\left(24 \mathrm{~h}\right.$ at $\left.103^{\circ} \mathrm{C}\right), \mathrm{N}$ content using the AOAC (1990) method (988.05) adapted for an automatic distiller Kjeldahl (Kjeltec Auto 1030 Analyzer; Tecator AB, Höganäs, Sweden) and using $\mathrm{CuSO}_{4} / \mathrm{Se}$ as a catalyst instead of $\mathrm{CuSO}_{4} / \mathrm{TiO}_{2}$; ether extract using the AOAC (1990) method (920.39), using petroleum ether for distillation instead of diethyl ether; and NDF and ADF following Van Soest et al. (1991), with sodium sulfite and heat-stable $\alpha$-amylase.

\section{Calculations and Statistical Analysis}

Data pertaining to $\mathrm{BW}$ and $\mathrm{ADG}$ from entrance until preweaning (52 d of age) were analyzed using an 
Table 1. Ingredient and nutrient composition of the starter feed and the TMR used in the current study

\begin{tabular}{|c|c|c|c|c|}
\hline Item & $\begin{array}{l}\text { Starter } \\
\text { feed }\end{array}$ & $\begin{array}{c}\text { TMR } \\
(59 \text { to } 110 \mathrm{~d})\end{array}$ & $\begin{array}{c}\text { TMR } \\
\text { (111 to } 160 \mathrm{~d})\end{array}$ & $\begin{array}{c}\text { TMR } \\
\text { (161 to } 228 \mathrm{~d})\end{array}$ \\
\hline \multicolumn{5}{|l|}{ Ingredient, $\%$ of DM } \\
\hline Ryegrass hay & - & 4.9 & 25.1 & - \\
\hline Wheat straw & - & 3.2 & 5.8 & 19.9 \\
\hline Corn silage & - & - & - & 5.2 \\
\hline High-moisture corn & - & - & - & 12.7 \\
\hline Brewers grains & - & - & - & 5.7 \\
\hline Wheat middlings & 29.6 & 27.2 & 14.7 & 9.9 \\
\hline Corn (cracked) & 20 & 35.4 & 32.3 & 16.5 \\
\hline Oats (whole) & 19.6 & 5.5 & - & - \\
\hline Soybean hulls & 8.4 & 6.7 & 8.8 & 4.8 \\
\hline Soybean meal & 8 & 11 & 11 & 1.5 \\
\hline Sunflower meal & - & - & - & 9.4 \\
\hline Canola meal & - & - & - & 12.7 \\
\hline Corn gluten meal & 7.3 & 2.5 & - & - \\
\hline Carob & 5.2 & 2 & - & - \\
\hline Molasses & - & - & 1.5 & 1.1 \\
\hline Calcium carbonate & 0.8 & 0.7 & 0.4 & 0.3 \\
\hline Sodium chloride & 0.5 & 0.5 & 0.2 & 0.2 \\
\hline \multirow{2}{*}{\multicolumn{5}{|c|}{ Nutrient $^{2}$}} \\
\hline & & & & \\
\hline DM, \% & 89 & 88.8 & 88.2 & 64.3 \\
\hline $\mathrm{CP}$ & 20.4 & 17.7 & 16.9 & 16.6 \\
\hline Ether extract & 4.1 & 3.5 & 3.1 & 3.2 \\
\hline $\mathrm{NDF}$ & 20.5 & 26.6 & 30.6 & 35.6 \\
\hline $\mathrm{ADF}$ & 8.7 & 12.8 & 16.98 & 21.3 \\
\hline $\mathrm{ME},{ }^{3} \mathrm{Mcal} / \mathrm{kg}$ & 3.46 & 3.02 & 2.89 & 2.47 \\
\hline
\end{tabular}

${ }^{1}$ The premix for the starter provided (on a DM basis) $1 \mathrm{kIU}$ of vitamin $\mathrm{A} / \mathrm{kg}, 120 \mathrm{IU}$ of vitamin $\mathrm{D} / \mathrm{kg}, 10 \mathrm{IU}$ of vitamin $\mathrm{E} / \mathrm{kg} ; 3,000 \mathrm{mg}$ of $\mathrm{Cu} / \mathrm{kg}, 5,000 \mathrm{mg}$ of $\mathrm{Mn} / \mathrm{kg}, 90 \mathrm{mg}$ of I/ $\mathrm{kg}, 9,300 \mathrm{mg}$ of Zn/ $\mathrm{kg}, 22 \mathrm{mg}$ of $\mathrm{Co} / \mathrm{kg}$, $90 \mathrm{mg}$ of $\mathrm{Se} / \mathrm{kg}$, and 4,000 $\mathrm{mg}$ of $\mathrm{Fe} / \mathrm{kg}$.

${ }^{2}$ Percentage of DM (unless otherwise indicated), determined as described in the text.

${ }^{3}$ Calculated according to NRC (2001).

ANOVA that accounted for the effects of block (age of entrance) and treatment. Data pertaining to starter feed and MR intake from entrance until preweaning (52 d of age) were analyzed using a mixed-effects model that accounted for the fixed effect of block (age of entrance; either 9 or $16 \mathrm{~d}$ ), treatment, day, and the interaction between day and treatment, and the random effect of calf within treatment. Day entered the model as a repeated measure with an autoregressive order 1 variance-covariance structure, which yielded the smallest Bayesian information criterion. Initially, a model similar to the one described above was run, including the random effect of herd of origin, but because this effect had no significant effect it was removed from the final model.

The data pertaining to starter feed and nutrient intakes, BW, and ADG from preweaning to completion of the study were analyzed using a mixed-effects model that accounted for the fixed effects of block (age of entrance; either 9 or $16 \mathrm{~d}$ ), treatment, time, and the interaction between treatment and time, plus the random effect of pen within treatment, with pen as the experimental unit. Time entered the model as a repeated measure using an autoregressive order 1 vari- ance-covariance structure, which yielded the smallest Bayesian information criterion.

Feed efficiency was calculated by dividing BW accretion by total DMI (both starter feed and MR). Potential differences in feed efficiency were then assessed using an ANOVA, with the effect of treatment and age group (block) for the data pertaining to the period between entrance and preweaning (52 d). Once animals were grouped until weaning ( $73 \mathrm{~d}$ of age), feed efficiency was assessed on a pen basis $(n=4)$, and data were analyzed as a 2-level mixed-effects model that accounted for the dependence of calves within pen, including the fixed effects of block (age of entrance; either 9 or $16 \mathrm{~d}$ ) and treatment, plus the random effect of pen and animal within pen.

Incidences of diarrhea and BRD were summarized individually until preweaning $(52 \mathrm{~d})$ and per pen $(\mathrm{n}=$ 4) after grouping. Data were analyzed using logistic regression and odds ratios (OR) for diarrhea, BRD, and relapses and were calculated with the LMR group as the reference group. Therefore, an OR of 1 represents an equal likelihood of disease in a particular group, whereas an OR $>1$ indicates a greater likelihood of that particular disease occurring relative to the LMR. 


\section{RESULTS AND DISCUSSION}

\section{Animal Performance}

Calves entered the study with an average age of 12 $\mathrm{d}$ and were grouped in 2 blocks according to age (9 and $16 \mathrm{~d}$ ). Interestingly, the effect of block (age of entrance) had no effect on overall $\mathrm{BW}(P=0.13)$ and only tended to result in an overall greater ADG (mean $\pm \mathrm{SE})$ in calves entering at $9 \mathrm{~d}$ old $(998 \pm 20.4 \mathrm{~g} / \mathrm{d})$ than in those entering at $16 \mathrm{~d}$ of age $(955 \pm 16.7 \mathrm{~g} / \mathrm{d})$. However, calves that enrolled in the study at $9 \mathrm{~d}$ of age tended $(P=0.06)$ to consume less dry feed $(302 \pm 30.0$ $\mathrm{g} / \mathrm{d})$ up to $52 \mathrm{~d}$ of age than calves that enrolled at $16 \mathrm{~d}$ of age $(384 \pm 30.1 \mathrm{~g} / \mathrm{d}$; data not shown). Nevertheless, a model that included the interaction between age of entrance and treatment was run for all parameters and in no case was the interaction found to be less than $P$ $=0.20$, which would suggest that any potential effects of feeding and management before entering the study were cancelled by the randomized allocation of calves to treatments.

Due to the experimental design, MR consumption until $52 \mathrm{~d}$ of age was greater $(P<0.001)$ in HMR than in LR calves (Table 2). As a consequence, LMR calves consumed more $(P<0.001)$ solid feed than HMR calves (Table 2) until $52 \mathrm{~d}$ of age. Several authors have reported that solid feed consumption decreases as MR allowance increases (Khalili et al., 1992; Jasper and Weary, 2002; Terré et al., 2006), although some have reported increased starter feed intake when feed- ing more MR (Kristensen et al., 2007; Hill et al., 2009). Also as expected, as age increased, dry feed consumption increased $(P<0.001)$, but LMR showed a more marked $(P<0.001)$ increase compared with HMR calves (Figure 1). After $30 \mathrm{~d}$ of the study, LMR calves clearly consumed more starter than HMR calves, suggesting that perhaps about $45 \mathrm{~d}$ of age would be a good moment to reduce MR offered to HMR calves to foster solid feed consumption and avoid the slump in ADG following weaning commonly observed when offering large milk allowances. However, despite the greater solid feed intake of LMR calves, HMR grew faster $(P<$ 0.003) than LMR calves until preweaning time (Figure 2 ), because total energy and protein consumption was greater $(P<0.001)$ in HMR than in LMR calves until $52 \mathrm{~d}$ of age (Table 2).

From preweaning to weaning, all calves received the same amount of MR and no differences were observed in solid feed intake $(\mathrm{n}=4)$. However, LMR calves had a greater $(P<0.05)$ ADG (of more than $100 \mathrm{~g} / \mathrm{d}$ ) than HMR calves (Figure 2). One reason for the greater ADG in LMR than HMR calves during preweaning could be that the reduction of MR from 8 to $4 \mathrm{~L} / \mathrm{d}$ in HMR calves was too abrupt and calves struggled to improve solid feed intake (which was about $120 \mathrm{~g} / \mathrm{d}$ numerically lower than in LMR calves). This might have been avoided by a more gradual reduction in MR allowance and highlights the potential importance of the weaning strategy when feeding large amounts of milk. Another reason to explain the improved ADG in

Table 2. Intake and performance of calves as affected by level of milk replacer (MR): $6 \mathrm{~L}$ of MR/d (LMR) versus $8 \mathrm{~L}$ of MR/d (HMR)

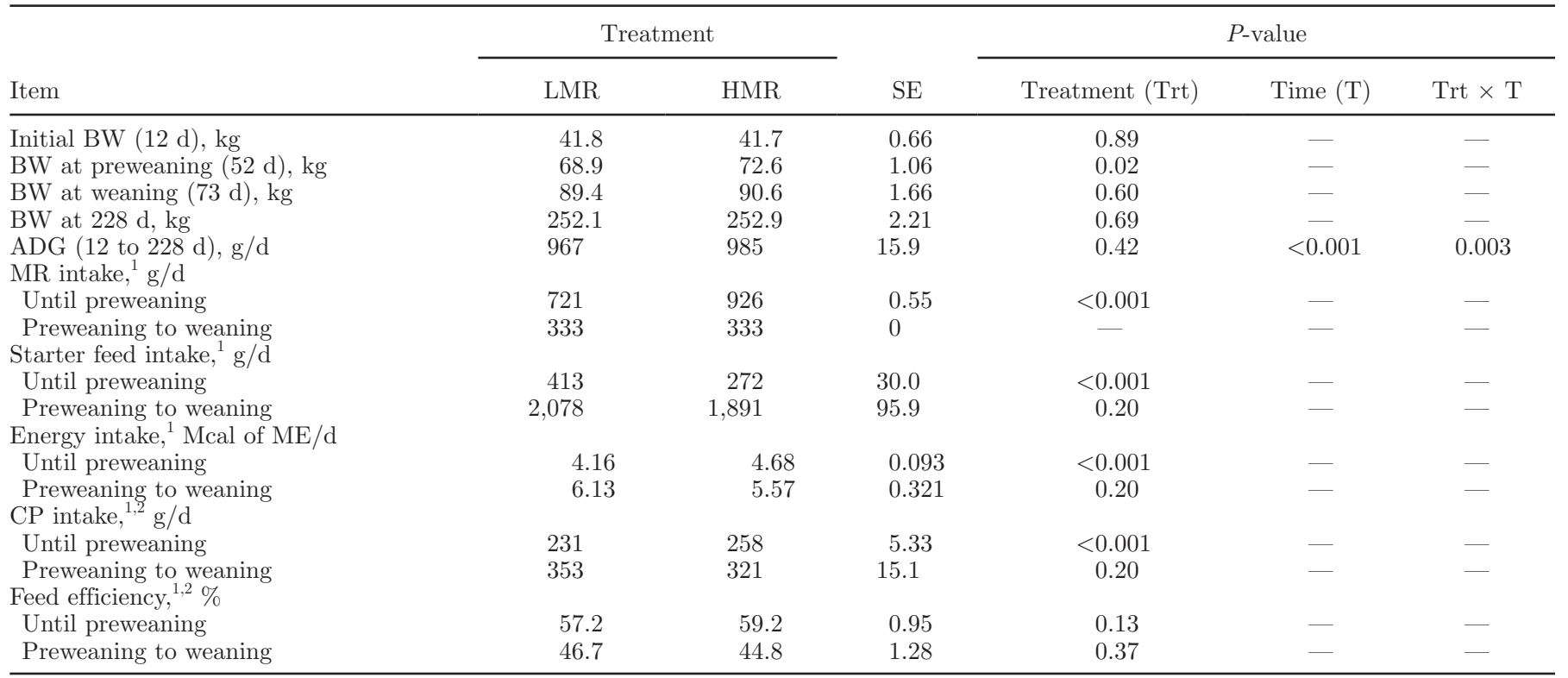

${ }^{1}$ Results for preweaning correspond to data collected individually $(\mathrm{n}=40)$, whereas intake values between preweaning and weaning correspond to data collected by group $(\mathrm{n}=4)$.

${ }^{2}$ Feed efficiency was calculated as BW accretion divided by total DMI (starter feed plus MR) expressed as percent $(\times 100)$. 


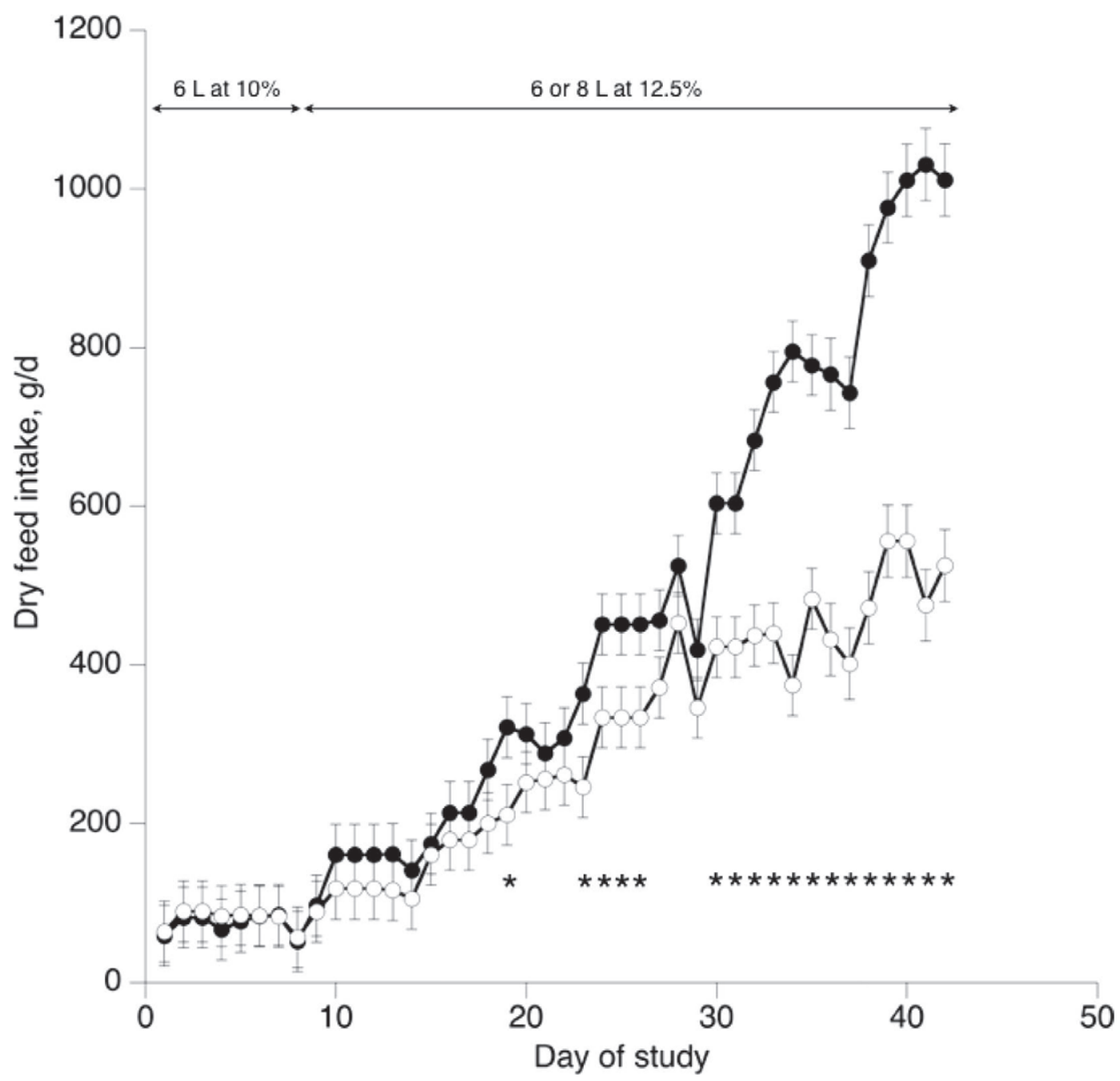

Figure 1. Evolution of dry feed intake during the first $42 \mathrm{~d}$ of the study as affected by the level of milk replacer (MR). Open circles denote $8 \mathrm{~L}$ of MR/d (HMR) and solid circles depict $6 \mathrm{~L}$ of MR/d (LMR). Asterisks indicate days of study when dry feed consumption differed $(P<$ $0.05)$ between LMR and HMR calves. Error bars represent the SE at each time point.

LMR compared with HMR calves in the absence of a difference in starter feed (although numerically it was also greater) and MR intakes could lead to a potential increase in DM digestibility. Terré et al. (2007) reported that calves fed relatively large amounts of MR (up to $1,260 \mathrm{~g}$ of DM/d) had lower DM and NDF digestibilities compared with calves fed low amounts of MR (up to $500 \mathrm{~g}$ of $\mathrm{DM} / \mathrm{d}$ ) during the week after weaning. More recently, Hill et al. (2010) reported similar findings when comparing MR allowances of 0.66 versus 1.09 $\mathrm{kg}$ of $\mathrm{MR} / \mathrm{d}$. A third possibility could be that the relatively more abrupt reduction in MR allowance in HMR than in LRM calves may have increased the stress level in the former group of calves and increased competition for the MR when offered in a trough. However, this hypothesis is unlikely because no differences in coefficient of variation in ADG (that could be used as a proxy for intake) between the HMR and LMR groups were found during both preweaning $(12.6 \pm 1.56$ vs. $13.2 \pm 1.56 \%$, respectively; $P=0.66)$ and after weaning $(23.5 \pm 4.23$ vs. $20.5 \pm 4.23 \%$, respectively; $P=0.48$ ). In fact, Bach et al. (2010) reported that when calves are weaned in groups, they do better in terms of performance and health (and most likely have a lower level of stress) than calves weaned in isolation.

After weaning (73 d), no differences were observed in ADG between LMR and HMR calves up to about 7 mo of age (Figure 2). Thus, BW of calves at weaning (73 d of life) was not affected by MR allowance and final BW at $228 \mathrm{~d}$ of life was not different between the 2 treatments (Table 2). Part of the lack of differences in BW and ADG was probably due to the method of weaning imposed in this study, which may have been too aggressive for the HMR calves. 


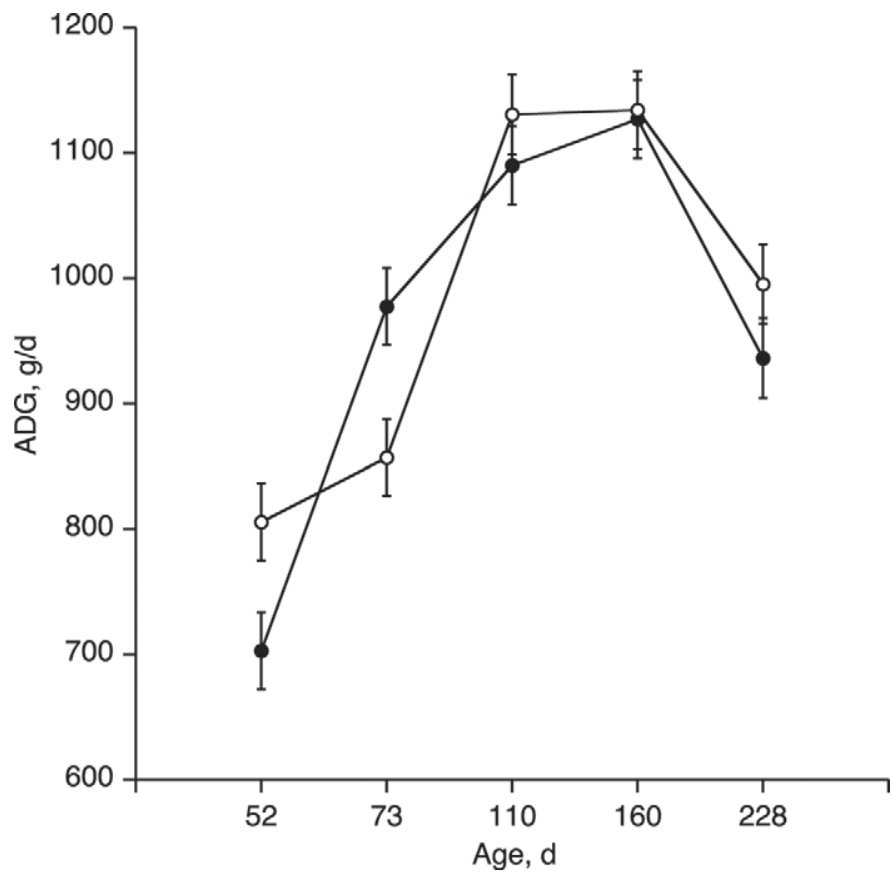

Figure 2. Evolution of ADG (g/d) with age as affected by the level of milk replacer (MR) offered. Open circles denote $8 \mathrm{~L}$ of MR/d (HMR) and solid circles depict $6 \mathrm{~L}$ of MR/d (LMR). Error bars represent the SE at each time point.

Feed efficiency was not affected by MR allowance (Table 2). In general, when comparing an allowance of approximately $500 \mathrm{~g} / \mathrm{d}$ with allowances up to 1,000 $\mathrm{g} / \mathrm{d}$, feed efficiency increases as MR allowance increases (Huber et al., 1984; Terré et al., 2007; Hill et al., 2009). In the current study, only numerical improvements in feed efficiency were observed in HMR compared with LMR before preweaning, and between preweaning and weaning this numerical difference was reversed. The proportion of total DMI that was consumed in the form of starter feed (data not shown) between the beginning of the study and preweaning time $(52 \mathrm{~d})$ was greater $(42.1 \pm 3.14 \%)$ in LMR compared with HMR calves $(22.6 \pm 3.14 \%)$. Interestingly, within the LMR calves, those that consumed more solid feed (and thus had a greater percentage of the DM consumed in the form of solid feed) before preweaning were more efficient $(P<$ 0.05 ) than those that consumed less solid feed (Figure $3 \mathrm{~A})$. However, within the HMR calves, no correlation was observed between the proportion of solid feed intake and feed efficiency (Figure 3B). Three potential reasons exist to explain the lack of response in feed efficiency in HMR calves as the proportion of solid feed in the form of starter increased. The first reason could be that HMR calves were at their maximum growth conversion efficiency. However, other studies (Bach et al., 2007; Terré et al., 2007; Stamey et al., 2012) have reported greater feed efficiencies than the ones reported herein;
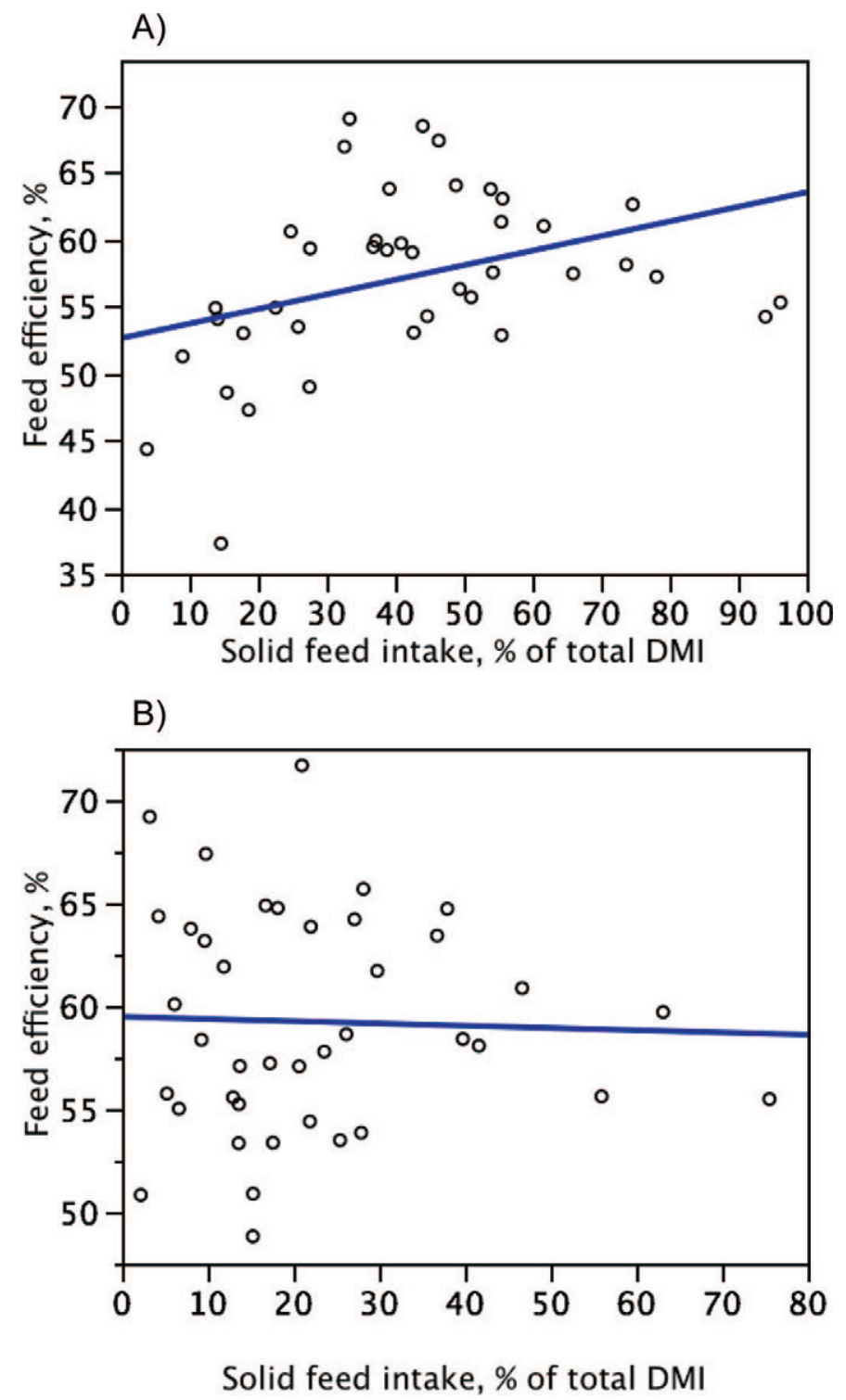

Figure 3. Relationship between starter feed intake before preweaning (d 52 of life) as a proportion of total DMI and feed efficiency as affected by milk replacer (MR) allowance. (A) Calves consuming $6 \mathrm{~L}$ of $\mathrm{MR} / \mathrm{d}\left(\mathrm{R}^{2}=0.16 ; P=0.02\right)$. (B) Calves consuming $8 \mathrm{~L}$ of $\mathrm{MR} / \mathrm{d}\left(\mathrm{R}^{2}\right.$ $=0.001 ; P=0.83)$. Color version available in the online PDF.

thus, this reason seems unlikely. A second potential reason could be that as more MR is offered, digestibility of the starter feed decreases, as reported elsewhere (Terré et al., 2007; Hill et al., 2010), and thus the additional nutrients consumed are not efficiently utilized. A third potential reason could be a decreased insulin sensitivity of HMR due to the relative large volume MR supplied. Increases of insulin resistance have been associated with a tendency toward fattening (Sillence, 2004) and, thus, feed efficiency should worsen (Hostettler-Allen et al., 1994). Bach et al. (2013) showed that providing $8 \mathrm{~L}$ of $\mathrm{MR} / \mathrm{d}$ in 2 daily allotments of $4 \mathrm{~L}$ each induced an 
Table 3. Incidence and odds ratio (OR) of pathology as affected by level of milk replacer (MR) offered and age at entrance: $6 \mathrm{~L}$ of MR/d (LMR) or $8 \mathrm{~L}$ of $\mathrm{MR} / \mathrm{d}(\mathrm{HMR})^{1}$

\begin{tabular}{|c|c|c|c|c|c|}
\hline Pathology & LMR & HMR & OR: LMR vs. HMR & $95 \% \mathrm{CI}^{2}$ & $P$-value \\
\hline Individually housed $(<52 \mathrm{~d}), \%$ & 12.5 & 12.5 & 1 & - & 1.0 \\
\hline Relapses, $\%$ of affected & 0.0 & 50.0 & - & - & 0.14 \\
\hline \multicolumn{6}{|l|}{ Diarrhea } \\
\hline Individually housed $(<52 \mathrm{~d}), \%$ & 52.5 & 45.0 & 1.38 & $0.98-2.02$ & 0.49 \\
\hline Relapses, $\%$ of affected & - & 0.0 & - & - & - \\
\hline
\end{tabular}

${ }^{1}$ Results for individually housed calves correspond to data collected individually $(\mathrm{n}=40)$ and results pertaining to group-housed calves correspond to data collected by group $(\mathrm{n}=4)$.

${ }^{2}$ Confidence interval for OR.

increase in insulin resistance in calves compared with calves that received $4 \mathrm{~L}$ of $\mathrm{MR} / \mathrm{d}(2 \mathrm{~L}$ per allotment). However, in that study, calves were fed MR in 2 daily allotments and the authors actually hypothesized that if more daily allotments were offered (as herein), the results may differ.

\section{Incidence of Disease}

Regarding health status, while calves were individually housed, no differences were observed in the incidence of BRD (Table 3); however, $60 \%$ (3 calves) of the LMR calves affected by BRD had a relapse while individually housed, whereas no calves in the HMR relapsed during that period. Diarrhea incidence was much greater than that of BRD while calves were individually hutched; however, it did not differ between treatment groups. Interestingly, though, $62.5 \%$ of the calves that entered the study at $9 \mathrm{~d}$ of age experienced diarrhea (data not shown), and this number was greater $(P=0.01)$ than the $35 \%$ diarrhea cases recorded in the calves that entered the study at $16 \mathrm{~d}$ of age (independent of the assigned treatment).

Contrary to what occurred with BRD, HMR calves that experienced diarrhea tended $(P=0.10)$ to be more likely to relapse compared with LMR calves. Increases in diarrhea when feeding increased amounts of MR have been previously reported (Huber et al., 1984; Quigley et al., 2006). Contrary to the observations of BRD (where relapse rates were not influenced by age of entrance), calves that entered the study at $9 \mathrm{~d}$ of age and incurred diarrhea were more likely $(P=0.03)$ to experience a second case of diarrhea (20\% relapse rate; 5 calves in total) than those calves entering at $16 \mathrm{~d}$ of age ( $0 \%$ relapse rate).

Once animals were in groups $(\mathrm{n}=4)$, no differences existed in the incidence of BRD; however, calves that entered the study at $9 \mathrm{~d}$ of age had a greater $(P=$
$0.007)$ incidence of BRD (12.5\%) than those that entered at $16 \mathrm{~d}$ of age $(0 \%$; data not shown). In terms of relapses, no differences existed in BRD relapse rate between the 2 treatments. Contrary to the observations while calves were individually housed, the number of incidences of diarrhea while in groups did not differ between treatments (Table 3). Differences in diarrhea relapses could not be assessed because no LMR calves incurred diarrhea and none of the HMR calves that had diarrhea while in groups relapsed.

\section{CONCLUSIONS}

Before preweaning, calves on $8 \mathrm{~L}$ of $\mathrm{MR}$ grew more than those offered $6 \mathrm{~L}$, but between preweaning and weaning, if milk replacer allowance was reduced from 8 or 6 to $4 \mathrm{~L} / \mathrm{d}$, calves on $6 \mathrm{~L} / \mathrm{d}$ grew more than those previously offered $8 \mathrm{~L} / \mathrm{d}$, and no differences were obtained in BW at weaning and at $228 \mathrm{~d}$ of life. In addition, no differences in BRD (although calves on $6 \mathrm{~L}$ of MR per day had more relapses) or diarrhea incidence (although calves on $8 \mathrm{~L}$ of MR per day tended to have more relapses) should be expected. Last, based on solid feed consumption patterns seen in this study, we determined that the optimum age to reduce MR allowances and foster solid feed intake is around $45 \mathrm{~d}$ of age.

\section{ACKNOWLEDGMENTS}

The authors are grateful to Rancho Las Nieves (Mallén, Spain) for allowing the development of this study in their facilities.

\section{REFERENCES}

AOAC (Association of Official Analytical Chemists). 1990. Official Methods of Analysis. AOAC, Arlington, VA.

Bach, A. 2011. Associations between several aspects of heifer development and dairy cow survivability to second lactation. J. Dairy Sci. 94:1052-1057. 
Bach, A. 2012. Ruminant Nutrition Symposium: Optimizing Performance of the Offspring: Nourishing and managing the dam and postnatal calf for optimal lactation, reproduction, and immunity. J. Anim. Sci. 90:1835-1845.

Bach, A., and J. Ahedo. 2008. Record keeping and economics of dairy heifers. Vet. Clin. North Am. Food Anim. Pract. 24:117-138.

Bach, A., J. Ahedo, and A. Ferrer. 2010. Optimizing weaning strategies of dairy replacement calves. J. Dairy Sci. 93:413-419.

Bach, A., L. Domingo, C. Montoro, and M. Terré. 2013. Short communication: Insulin responsiveness is affected by the level of milk replacer offered to young calves. J. Dairy Sci. 96:4634-4637.

Bach, A., A. Giménez, J. L. Juaristi, and J. Ahedo. 2007. Effects of physical form of a starter for dairy replacement calves on feed intake and performance. J. Dairy Sci. 90:3028-3033.

Baldwin, R. L., VI, K. R. McLeod, J. L. Klotz, and R. N. Heitmann. 2004. Rumen development, intestinal growth and hepatic metabolism in the pre- and postweaning ruminant. J. Dairy Sci. 87(E. Suppl.):E55-E65.

Borderas, T. F., J. Rushen, M. A. G. von Keyserlingk, and A. M. B. de Passillé. 2009. Automated measurement of changes in feeding behavior of milk-fed calves associated with illness. J. Dairy Sci. 92:4549-4554.

Castells, L., A. Bach, G. Araujo, C. Montoro, and M. Terré. 2012. Effect of different forage sources on performance and feeding behavior of Holstein calves. J. Dairy Sci. 95:286-293.

Castells, L., A. Bach, A. Aris, and M. Terré. 2013. Effects of forage provision to young calves on rumen fermentation and development of the gastrointestinal tract. J. Dairy Sci. 96:5226-5236.

Cowles, K. E., R. A. White, N. L. Whitehouse, and P. S. Erickson. 2006. Growth characteristics of calves fed an intensified milk replacer regimen with additional lactoferrin. J. Dairy Sci. 89:48354845.

Davis, C. L., and J. K. Drackley. 1998. Effect of changes in environmental temperature and energy metabolism. Pages 79-89 in The Development, Nutrition, and Management of the Young Calf. Iowa State Univ. Press, Ames.

Díaz, M. C., M. E. Van Amburgh, J. M. Smith, J. M. Kelsey, and E. L. Hutten. 2001. Composition of growth of Holstein calves fed milk replacer from birth to 105-kilogram body weight. J. Dairy Sci. 84:830-842.

Hill, T. M., H. G. Bateman II, J. M. Aldrich, and R. L. Schlotterbeck. 2009. Effect of weaning age of dairy calves fed a conventional or more optimum milk replacer program. Prof. Anim. Sci. 25:619624 .

Hill, T. M., H. G. Bateman II, J. M. Aldrich, and R. L. Schlotterbeck. 2010. Effect of milk replacer program on digestion of nutrients in dairy calves. J. Dairy Sci. 93:1105-1115.

Hostettler-Allen, R. L., L. Tappy, and J. W. Blum. 1994. Insulin resistance, hyperglycemia, and glucosuria in intensively milk-fed calves. J. Anim. Sci. 72:160-173.

Huber, J. T., A. G. Silva, O. F. Campos, and C. M. Mathieu. 1984 Influence of feeding different amounts of milk on performance, health, and absorption capability of baby calves. J. Dairy Sci. 67:2957-2963.

Jasper, J., and D. M. Weary. 2002. Effects of ad libitum milk intake on dairy calves. J. Dairy Sci. 85:3054-3058.

Kehoe, S. I., C. D. Dechow, and A. J. Heinrichs. 2007. Effects of weaning age and milk feeding frequency on dairy calf growth, health and rumen parameters. Livest. Sci. 110:267-272.
Khalili, H., S. Crosse, and T. Varvikko. 1992. The performance of crossbred dairy calves given different levels of whole milk and weaned at different ages. Anim. Prod. 54:191-195.

Khan, M. A., H. J. Lee, W. S. Lee, H. S. Kim, S. B. Kim, K. S. Ki, J. K. Ha, H. G. Lee, and Y. J. Choi. 2007. Pre- and postweaning performance of Holstein female calves fed milk through step-down and conventional methods. J. Dairy Sci. 90:876-885.

Kristensen, N. B., J. Sehested, S. K. Jensen, and M. Vestergaard. 2007. Effect of milk allowance on concentrate intake, ruminal environment, and ruminal development in milk-fed Holstein calves. J. Dairy Sci. 90:4346-4355.

Larson, L. L., F. G. Owen, J. L. Albright, R. D. Appleman, R. C. Lamb, and L. D. Muller. 1977. Guidelines toward more uniformity in measuring and reporting calf experimental data. J. Dairy Sci. 60:989-991.

Montoro, C., E. Miller-Cushon, T. J. DeVries, and A. Bach. 2013. Effect of physical form of forage on performance, feeding behavior, and digestibility of Holstein calves. J. Dairy Sci. 96:1117-1124.

Nocek, J. E., and D. G. Braund. 1986. Performance, health, and postweaning growth on calves fed cold, acidified milk replacer ad libitum. J. Dairy Sci. 69:1871-1883.

Nonnecke, B. J., M. R. Foote, J. M. Smith, B. A. Pesch, and M. E. Van Amburgh. 2003. Composition and functional capacity of blood mononuclear leukocyte populations from neonatal calves on standard and intensified milk replacer diets. J. Dairy Sci. 86:3592-3604.

NRC. 2001. Nutrient Requirements of Dairy Cattle. 7th rev. ed. Natl. Acad. Press, Washington, DC.

Pollock, J. M., T. G. Rowan, J. B. Dixon, and S. D. Carter. 1994. Level of nutrition and age at weaning: Effects on humoral immunity in young calves. Br. J. Nutr. 71:239-248.

Quigley, J. D., T. A. Wolfe, and T. H. Elsasser. 2006. Effects of additional milk replacer feeding on calf health, growth, and selected blood metabolites in calves. J. Dairy Sci. 89:207-216.

Roth, B. A., N. M. Keil, L. Gygax, and E. Hillmann. 2009. Influence of weaning method on health status and rumen development in dairy calves. J. Dairy Sci. 92:645-656.

Sillence, M. N. 2004. Technologies for the control of fat and lean deposition in livestock. Vet. J. 167:242-257.

Soberon, F., E. Raffrenato, R. W. Everett, and M. E. Van Amburgh. 2012. Preweaning milk replacer intake and effects on long-term productivity of dairy calves. J. Dairy Sci. 95:783-793

Stamey, J. A., N. A. Janovick, A. F. Kertz, and J. K. Drackley. 2012. Influence of starter protein content on growth of dairy calves in an enhanced early nutrition program. J. Dairy Sci. 95:3327-3336.

Terré, M., M. Devant, and A. Bach. 2006. Performance and nitrogen metabolism of calves fed conventionally or following an enhancedgrowth feeding program during the preweaning period. Livest. Sci. 105:109-119.

Terré, M., M. Devant, and A. Bach. 2007. Effect of level of milk replacer fed to Holstein calves on performance during the preweaning period and starter digestibility at weaning. Livest. Sci. 110:82-88.

Van Soest, P. J., J. B. Robertson, and B. A. Lewis. 1991. Methods for dietary fiber, neutral detergent fiber, and nonstarch polysaccharides in relation to animal nutrition. J. Dairy Sci. 74:3583-3597. 